\title{
IMPACT OF YEAST GENETICS AND MOLECULAR BIOLOGY ON TRADITIONAL AND NEW BIOTECHNOLOGY
}

\author{
ANNA MARÁZ \\ Department of Microbiology and Biotechnology, University of Horticulture and Food Industry, \\ Budapest, Hungary
}

\begin{abstract}
Developments in yeast genetics, biochemistry, physiology and process engineering provided bases of rapid development in modern biotechnology. Elaboration of the recombinant DNA technique is far the most important milestone in this field. Other molecular genetic techniques, as molecular genotyping of yeast strains proved also very beneficial in yeast fermentation technologies. Saccharomyces cerevisiae is the most exploited eukaryotic microorganism in biotechnology but non-Saccharomyces species are becoming more and more important in the production of perfectly translated heterologous proteins.
\end{abstract}

Importance of yeasts in traditional biotechnology is enormous. In food and beverage fermentation processes a wide range of yeast species are playing a role, but Saccharomyces cerevisiae is undoubtedly the most important species among them. New biotechnology is aiming to improve these technologies, but besides this, a completely new area of yeast utilization has been emerged, especially in the pharmaceutical and medical areas. Without decreasing the importance of $S$. cerevisiae, numerous other yeast species, e.g. Kluyveromyces lactis, Hansenula polymorpha, Pichia pastoris, Schizosaccharomyces pombe and Yarrowia lipolytica have gained increasing potentialities in the modern fermentation biotechnology.

Developments in yeast genetics, biochemistry, physiology and process engineering provided bases of rapid development in modern biotechnology, but elaboration of the recombinant DNA technique is far the most important milestone in this field. Other molecular genetic techniques, as molecular genotyping of yeast strains proved also very beneficial in yeast fermentation technologies, because dynamics of both the natural and inoculated yeast biota could be followed by these versatil DNA-based techniques.

Impact of yeast genetics on alcoholic beverage technologies

Roots of classical yeast genetics go back to the early work of Lindegreen in the 1930 s, who studied thallism, sporulation and inheritance of wine yeast strains belonging to $S$. cerevisiae. Consequent mutation and hybridization of heterothallic $S$. cerevisae

ANNA MARÁZ

Department of Microbiology and Biotechnology, University of Horticulture and Food Industry P.O. Box 53, H-1502 Budapest, Hungary 
strains resulted in the discovery of life cycle and mating type system, as well as construction of the genetic map. Elaboration of induced mutation and controlled hybridization of yeast strains opened up new possibilities for the genetic analysis of technologically important properties and for the production of improved industrial strains, but a big drawback was the widely different genetic properties of laboratory and industrial yeast strains. Genetic analysis and mapping of industrial strains were generally hindered because of homothallism, poor sporulation and/or low spore viability of brewing and wine yeast strains $[1,2]$. In spite of this there are a few examples of the application of sexual hybridization in the study of genetic control of important technological properties, e.g. sugar utilization, flocculation and flavour production in brewing yeast strains [3], or in the improvement of ethanol producing $S$. cerevisiae strains [4]. Rare mating and application of karyogamy deficient $\left(\mathrm{kar}^{-}\right)$mutants also proved useful in strain improvement [5].

Hybridization by protoplast fusion is circumventing most of the difficulties arising from polyploidy, homothallism and non-mating of the majority of industrial strains. Novel genetic properties can be effectively transferred to industrial yeasts from strains belonging to the same or closely related species (e.g. S. cerevisiae and S. bayanus). New wine yeast strains were constructed by fusion of genetically different wine yeast strains, when natural genetic markers and mitochondrial mutations were used in the selection of hybrids [6]. An other example is the construction of dextrin fermenting brewing yeast strain when the glucoamylase (STA) gene was transferred from an auxotrophic mutant of $S$. cerevisiae var. diastaticus into a lager yeast strain [7]. Karyotype analysis of hybrids and mitotic segregants obtained proved to be very useful in the selection of those descendants which harboured the most chromosomes of the original brewing yeast strain. A major drawback of the method is, however, that undesired properties are generally also transferred, so a labourious, time-consuming postselection work is needed. Cytoplasmic genetic determinants, as killer dsRNA molecules can also be easily introduced into industrial strains by induced fusion of protoplasts without transferring chromosomal genes [7].

Application of molecular typing methods in identification, classification and population studies of biotechnologically important yeasts

Yeast genome consists of chromosomes and mitochondrial DNA, sometime plasmids and viral nucleic acids are also found in the cells. Number and organization of chromosomal sets are typical for distinct species, while polymorphism of homologues chromosomes reflects difference or identity of strains belonging to the same species. Electrophoretic karyotyping is the most promising method in karyotype analysis, especially in industrial strains belonging to the Saccharomyces genus. Reproducable chromosomal fingerprints are obtained when intact chromosomes are separated under identical conditions of electrophoresis. Combination of electrophoretic karyotyping and Southern hybridization of special genes, Tamai and cowerkers [8] showed that the bottom fermenting brewing yeast, $S$ pastorianus has two types of chromosomes, $S$. cerevisiaetype and $S$. bayanus-type, and that these chromosomes co-exist independently without undergoing reciprocal rearrangements. $S$. pastorianus is thus a natural hybrid of $S$. cerevisiae and S. bayanus as was thought earlier by Vaughan Martini and Kurtzman [9]. 
Population kinetics of yeasts responsible for alcoholic fermentation of must depend on specific factors such as climate conditions, soil, wine grape varieties and also viticultural and enological practices used.

Electrophoretic karyotyping in combination with mitochondrial restriction fragment length polymorphism (RFLP) and PCR amplification of Ty elements were used by Versavaud and cowerkers [10] to study the variability, phylogenetic affinities and biogeographical distribution of wild $S$. cerevisiae enological yeast strains in a natural wine producing district, Charentes (France). They found only limited correlation between geographical location and genetic affinity, but one strain seemed to be distributed over the entire area surveyed.

In collaboration with a Slovenian research group we made comparative analysis of indigenous yeast biota on vine grapes and studied the yeast population kinetics during spontaneous and induced fermentation of "refosk" musts in selected cellars in Costal and Carst regions of Slovenia during two subsequent seasons. Among more than 500 isolates tested, extremely high inter- and intraspecific heterogeneity was observed on the basis of chromosome length polymorphism (CLP) of yeasts isolated from vineyards during different fermentation stages and also in starter culture induced fermentation. Only limited correlation was found between indigenous yeast flora in vineyards and wine fermentation, because all yeasts isolated from grapes were non-Saccharomyces yeasts. They belonged to the genera of Rhodotorula and Cryptococcus. In spite of this, Saccharomyces cerevisiae strains clearly dominated in all middle fermentation phases tested. Sequential substitution by Saccharomyces cerevisiae strains was observed along fermentation on the basis of electrophoretic karyotyping and RAPD-PCR analysis of these yeasts.

Killer yeasts

Killer yeasts are closely associated with the winemaking process. A number of wild killer yeasts from various genera have been isolated from grape must so far, some of these strains have caused stuck or slow fermentation. Occurrence of killer activity has been observed also among strains, which are employed in the commercial fermentation of wine (see the review by Shimizu [11]). Production of Tokaj wine is typical to the Hungarian wine-producing district, Tokajhegyalja. This technology involves extraction of overripe botrytized grapes either by dry wine or fermenting must. This is followed by a secondary fermentation with the help of wine yeast strains that survived the elevating ethanol concentration. Fermentation is finished by a long maturation, when the typical flavour and aroma compounds develop.

Killer, sensitive and neutral phenotype of the fermenting yeast populations was checked and killer strains were isolated from different stages of wine fermentation. Killer yeasts belonged to two phenotypes: one of them showed killing activity only at $\mathrm{pH} \mathrm{4}$, while the other was active at $\mathrm{pH} 5$, too.

Genetic determinants for the toxin production were found to be dsRNA plasmids in every killer strain that differed in the size of M dsRNA molecules. Killer toxins of activity at $\mathrm{pH} 4$ were associated with different M dsRNA molecules, but killer strains from the same fermentation always harboured M dsRNA of the same size.

Successive changes of the fermenting killer yeast populations were also monitored by molecular analysis of their nuclear genotypes. Electrophoretic karyotyping showed 
high degree of heterogeneity when yeast strains from different fermentation were compared, while more similarity was found when strains from the same fermentation were analysed. Both similarity and dissimilarity in the PFGE karyograms of the isolates were reflected in the cluster analysis of the RAPD-PCR profiles but more detailed distinction of strains that belonged to the same PFGE group was achieved by the latter method.

We used mitochondrial drug resistant mitochondrial mutants for studying the role of killer toxin produced in the competition of killer, sensitive and neutral wine yeast strains. Mitochondrial point mutations causing resistance against diuron were induced by manganese treatment of the killer wine yeast strains that were used in different ratio together with sensitive or neutral wine yeast strains in model fermentation. As the control, killer plasmid cured, diuron resistant strains were applied making possible to study the role of other competitive factors than the killer toxin.

Yeasts as cloning hosts in biotechnology

Yeasts are far the most frequently used cloning hosts in both the basic research and biotechnology among the eukaryotic microorganisms. The leading role of $S$. cerevisiae is indisputable, but numerous other species are becoming more and more important. The main reason of this is that post-translational modification of mammalian proteins by $S$. cerevisiae is not always perfect, especially O-linked glycosylation of maturing proteins is different, which endows antigenic property of mammalian proteins produced. Pichia pastoris, Hansenula polymorpha and Schwanniomyces occidentalis, however, glycosylate proteins similarly as higher eukaryotes [12]. There are some other advantages of the application of the formerly mentioned species; e.g. utilization of cheap carbon sources during propagation, lack of catabolite repression or excretion of heterologous proteins after having been synthesized. Undoubtedly, however, the well developed vector system, a big set of well-characterized mutants and mapped genes and the fully sequenced genome make $S$. cerevisiae the most important eukaryotic microorganism.

\section{Brewing yeasts}

Brewing yeasts can be considered as fully domesticated strains. Producing strains that are applied in controlled technological processes of beer production are the results of successive selection activity of the brewers. In spite of this, they are still not the ideal strains that could fulfil the demands of the technologists. Genetic modification by classical methods have contributed to the improvement of strains only in limited range, mainly due to the loss of meiosis hindering efficient application of mutagenesis and hybridization. Molecular biology opened up new possibilities for both the genetic analysis and strain improvement, what have been utilized in many areas. Promising genetically engineered brewing yeasts have been produced in several laboratories, which were tested also in semipilote or pilot scale beer fermentation's. Table I contains some examples of genetically engineered brewing yeast strains.

Wine yeasts

Fermentation of wine is attributed to the activity of many yeast species. Kloeckera apiculata, Hanseniaspora uvarum, Candida stellata, Torulaspora and Pichia spp. start fermentation and predominate in the early phase, while Saccharomyces cerevisiae 
becoming dominant soon, when the elevating ethanol content reaches $5 \%$. Selected wine yeast strains have been used as starter cultures, which overgrow the natural yeast biota

Table I

Practical application of recombinant DNA technique in the improvement of industrial yeasts

\begin{tabular}{|c|c|c|}
\hline Type of industrial yeast & New properties & Gene cloning \\
\hline \multirow{11}{*}{ Brewing yeast } & Fermentation of maltodextrins & Cloning of glucoamylase genes from \\
\hline & & Schwanniomyces spp. and \\
\hline & & S. cerevisiae var. diastaticus \\
\hline & $\begin{array}{l}\text { Degradation of } \beta \text {-glucan derived from } \\
\text { malted barley in wort - improvement of } \\
\text { filtration }\end{array}$ & $\begin{array}{l}\text { Cloning of B-glucanase genes from } \\
\text { bacteria, fungi and barley }\end{array}$ \\
\hline & $\begin{array}{l}\text { Hydrolysis of wort proteins - beer haze } \\
\text { prevention }\end{array}$ & $\begin{array}{l}\text { Genetic engineering for supersecretion of } \\
\text { protease }\end{array}$ \\
\hline & $\begin{array}{l}\text { Reduction of diacetyl level in beer - } \\
\text { decrease of maturation time }\end{array}$ & $\begin{array}{l}\text { Cloning of ALD, ALS and AR genes } \\
\text { from Enterobacter } \mathrm{sp} \text {. and Klebsiella sp. }\end{array}$ \\
\hline & Reduction of $\mathrm{H}_{2} \mathrm{~S}$ formation by yeast & Cloning of cystathionine syntase gene \\
\hline & $\begin{array}{l}\text { Increase of } \mathrm{SO}_{2} \text { production acting as } \\
\text { antioxidant and anticontaminant }\end{array}$ & $\begin{array}{l}\text { Site directed mutagenesis of sulphite } \\
\text { reductase gene (MET10) }\end{array}$ \\
\hline & $\begin{array}{l}\text { Increase of flocculation level at the end of } \\
\text { fermentation }\end{array}$ & Cloning of FLO1 gene \\
\hline & Derepression for glucose & Manipulation of MAL genes \\
\hline & $\begin{array}{l}\text { Improvement of wine filtration and fruity } \\
\text { aroma }\end{array}$ & $\begin{array}{l}\text { Cloning of pectinases and glucanases } \\
\text { from fungi }\end{array}$ \\
\hline \multicolumn{3}{|l|}{ Wine yeasts } \\
\hline & Malolactic fermentation & $\begin{array}{l}\text { Cloning of lactate dehydrogenase from } \\
\text { Lactobacillus sp. }\end{array}$ \\
\hline & Malo-alcoholic fermentation & $\begin{array}{l}\text { Cloning of malate permease and malic } \\
\text { enzyme from Schizosaccharomyces sp. }\end{array}$ \\
\hline \multirow{7}{*}{ Baker's yeast } & Increase of glycerol level & $\begin{array}{l}\text { Cloning of DHAP reductase and glycerol } \\
\text { phosphatase }\end{array}$ \\
\hline & $\begin{array}{l}\text { Construction of double killer toxin } \\
\text { producing yeast }\end{array}$ & $\begin{array}{l}\text { Transformation of cDNA of K1 } \\
\text { preprotoxin gene into K2 killer strain }\end{array}$ \\
\hline & $\begin{array}{l}\text { Improvement of flocculation of a } \\
\text { champagne yeast }\end{array}$ & Cloning of FLO5 gene from S. cerevisiae \\
\hline & Utilization of raffinose in molasses & $\begin{array}{l}\text { Cloning of melibiase gene from brewing } \\
\text { yeast }\end{array}$ \\
\hline & Increase of dough-raising ability & $\begin{array}{l}\text { Cloning of maltose permease and } \\
\text { maltase genes with strong promoters }\end{array}$ \\
\hline & $\begin{array}{l}\text { Avoidance of glucose repression of } \\
\text { maltose utilization genes }\end{array}$ & $\begin{array}{l}\text { Cloning of manipulated MAL gene from } \\
\text { yeast }\end{array}$ \\
\hline & $\begin{array}{l}\text { Derepression of maltase and invertase } \\
\text { synthesis }\end{array}$ & $\begin{array}{l}\text { Cloning of multiple copies of MAL and } \\
\text { SUC regulatory genes }\end{array}$ \\
\hline
\end{tabular}

Information mainly from Walker [15] 
and complete fermentation of must within a short time. Commercial starters are the results of not only selection but strain improvement, too. Improvement, what is accepted by the wine producers without any restrictions, can be achieved by mutagenesis and several varieties of hybridization, including protoplast fusion. Major achievements of such classical breeding experiments are new hybrids and killer wine yeast strains [13]. Recombinant DNA technology is in the phase of to revolutionize wine yeast strain improvement; the results are, however, mainly in experimental stage. Some examples of genetically engineered wine yeast strains are shown in Table I. Main directions of strain improvement are cloning heterologous enzyme genes of bacterial, yeast and fungal origin, and use the site-directed mutagenesis to modify metabolic genes having a role in flavour and aroma production.

Baker's yeasts

Baker's yeast manufacture is using selected $S$. cerevisiae strains, which have an accelerated growth in molasses containing sucrose as a carbon source. High dough leavening activity, cryotolerance and good storage stability are the most important characteristics what are expected from the yeast during bread making. Strain improvement by rDNA technique is aiming to increase biomass yield, to reduce fermentation time and to increase leavening activity. Genetically modified baker's yeast strain, constructed and patented by the Gist Brocades, contains derepressed promoters of maltase genes, and as a consequence, its leavening activity has been enhanced significantly. The British Government in 1991 for use in baking has approved this strain. There are other achievements of gene cloning in baker's yeast improvement, some of them is shown in Table I. by yeasts

Application of gene cloning in the production of enzymes and therapeutic proteins

Yeasts are generally considered as very poor sources of industrially useful compounds and enzymes, because they excrete just a few enzymes and overproduction of metabolites is very rare. This is true if someone concentrates only to the Saccharomyces species, but this picture is more promising if the wide natural biodiversity of nonSaccharomyces species are analyzed more carefully from biotechnological aspect (see the reviews by Wolf [14] and Walker [15]). Several non-Saccharomyces species seem also to be near the ideal host in cloning of heterologous genes of eukaryotes, as mentioned previously. More research is needed to utilize the gene pools of these species.

Starch hydrolyzing activity is very significant in some yeast species. Cloning the glucoamylase genes of Schwanniomyces and S. cerevisiae var. diastaticus in industrial ethanol producing strains of $S$. cerevisiae, bioethanol producing strains from industrial starch containing waste and raw material were constructed. The renewable energy sources, cellulose and hemicellulose can be directly converted into ethanol by $S$. cerevisiae, containing cloned cellulase and xylanase genes of various yeasts and fungi.

One of the major achievements of modern food biotechnology was the production of recombinant chymosin by Kluyveromyces lactis. Not only this product could substitute 
the calf rennin, but it was acceptable by certain religious people, who are not aloud to eat cheese processed by the calf rennin.

Recombinant vaccine against Hepatitis B was the first approved therapeutic yeast protein produced by Merck in 1986. Since that time several other antiviral, antibacterial and antimalaria proteins have been produced by $S$. cerevisiae and other yeast species. Recombinant human blood proteins, hormones, growth factors and antibodies are now available for medical purposes, or a yeast expression and production system has been successfully developed. Significance of yeasts as cloning hosts for the production of recombinant pharmaceuticals is increasing.

\section{REFERENCES}

1. Stewart,G.G.: The genetic manipulation of industrial yeast strains. Can J Microbiol 27, 973-990 (1981).

2. Thornton,R.J., Eschenbruch,R.: Homothallism of wine yeasts. Antonie van Leeuwenhoek, 42, 503 (1976).

3. Bilinski,C.A., Hatfield,D.E., Sobczak,J.A., Russell,I., Stewart,G.G.: Analysis of sporulation and segregation of polyploid brewing strain of Saccharomyces cerevisiae. In Stewart,G.G. et al. (eds): Biological Research on Industrial Yeasts. Vol. II. CRC Press, Boca Raton. 1987. pp. 37-47.

4. Christensen,B.E.: Cross breeding of distillers yeast by hybridization of spore derived clones. Carlsberg Res Commun 52, 253 (1987).

5. Kielland-Brandt,M.C., Nillson-Tillgren,T., Petersen,J.G.L., Holmberg,S., Gjermansen,C.: Approaches to the genetic analysis and breeding of brewer's yeast. In Spencer,J.F.T., Spencer,D.M., Smith,A.R.W. (eds): Yeast Genetics. Fundamental and applied aspects. Springer-Verlag, New York. 1983. pp. 421-437.

6. Maráz,A., Deák,T.: Production and analysis of improved enological yeast strains. Biotech Forum Europe 7 , 631990.

7. Maráz,A., Zákány,F., Lovenyák,M.: Improvement of brewing yeasts: Construction of killer and glucoamylase producing strains. Hungarian Agricultural Research 3, 34 (1994).

8. Tamai,Y., Momma,T., Yoshimoto,H., Kaneko,Y.: Co-existence of two types of chromosome in the bottom fermenting yeast, Saccharomyces pastorianus. Yeast 14, 923 (1998).

9. Vaughan Martini,A., Kurtzman,C.P.: Deoxyribonucleic acid relatedness among species of the genus Saccharomyces sensu stricto. Int J Syst Bacteriol 35, 508 (1985).

10. Versavaud,A., Courcoux,P., Roulland,C., Dulau,L., Hallet,J-N.: Genetic diversity and geographical distribution of wild Saccharomyces cerevisiae strains from the wine-producing area of Charentes, France. Appl Environ Microbiol 61, 3521 (1995).

11. Shimizu,K.: Killer yeasts. In Fleet,G.H. (ed.): Wine Microbiology and Biotechnology. Harwood Academic Publ GmbH, Chur, Switzerland. 1993. pp. 243-264.

12. Echart,M.R., Bussineau,C.M.: Quality and authenticity of heterologous proteins synthesised in yeast. Current Opinion in Biotechnology. 7, 525 (1996).

13. Barre,P., Vezinhet,F., Dequin,S., Blondin,B.: Genetic improvement of wine yeasts. In Fleet,G.H. (ed.): Wine Microbiology and Biotechnology. Harwood Academic Publ. Gmbh, Chur, Switzerland. 1993. pp. 265-287.

14. Wolf,K. (ed.): Nonconventional Yeasts in Biotechnology. A handbook. Springer Verlag, Berlin. 1996.

15. Walker,G.M.: Yeast Physiology and Biotechnology. John Wiley \& Sons, Ltd., Chichester. 1998. 